\title{
Coal Hydrogenation in Great Britain
}

THE daily discussion of 'oil sanctions' will have served a useful purpose if it brings home to the public the perilous position of Great Britain in regard to oil supplies in time of war. Actually the London omnibuses alone consume more fuel than the total quantity of benzole produced by coke ovens and gas works, whilst apart from the new has been supplemented recently by a technical paper issued by the Fuel Research Board* describing the earlier investigations of Bergius and the action of the Department, and its connexion with other bodies interested in the subject prior to the advent of I.C.I. This forms a valuable historical survey.

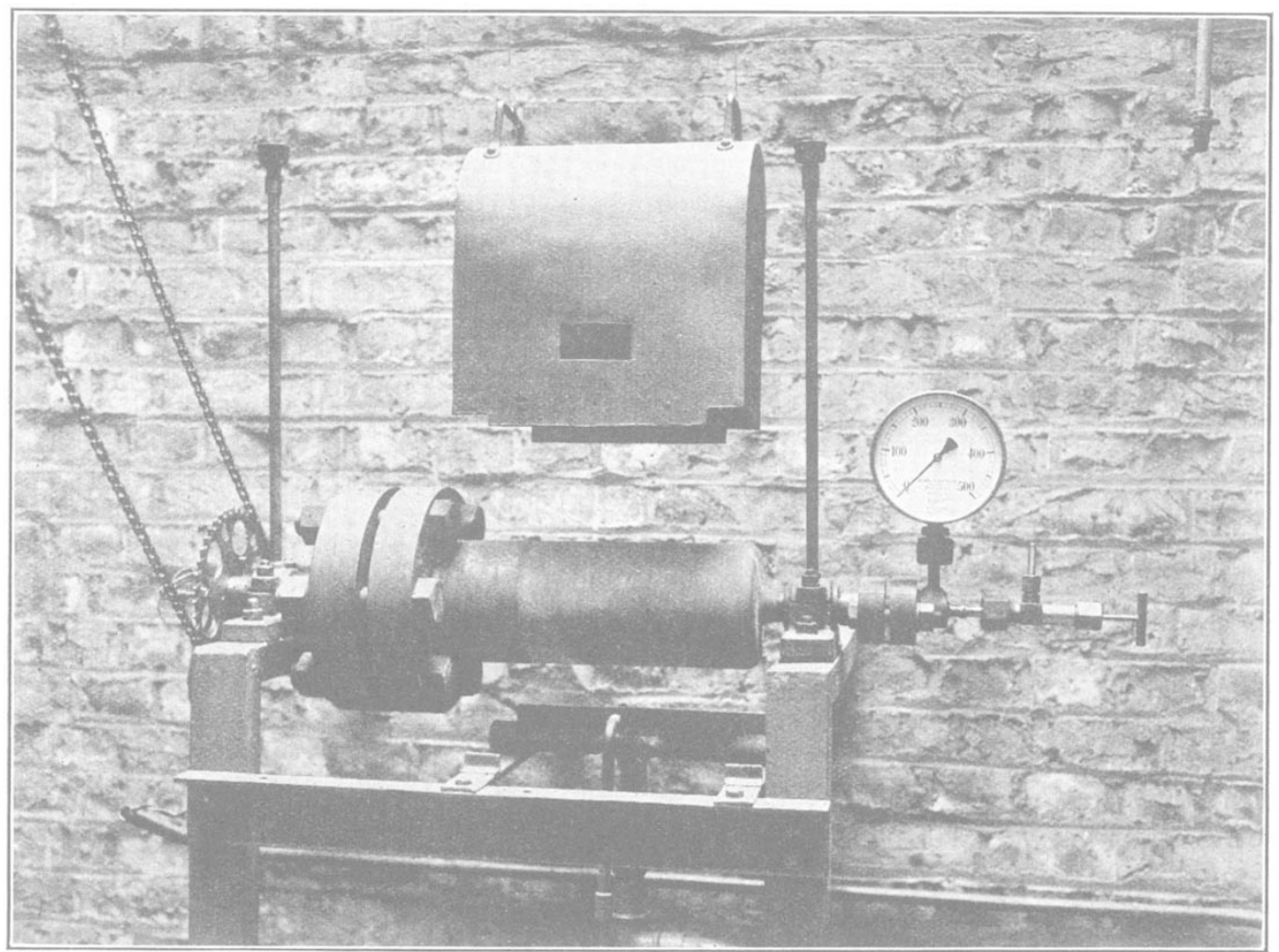

Fra. 1. Bergius 2-litre converter. From Fuel Research Technical Paper No. 42. Crown copyright reserved.

coal hydrogenation plant of Imperial Chemical Industries at Billingham, the total production of home-produced fuel is less than 7 per cent of British requirements. Germany is paying great attention to this same problem of producing oil internally and is already in a much more favourable position than Great Britain.

The main achievement in England so far is the hydrogenation of hard coal by a process, discovered by Bergius, developed by Imperial Chemical Industries, Ltd., as a member of the International Hydrogenation Patents Co., and brought into highly successful operation on a large scale at Billingham during last winter. The story of the achievement has been told in a paper read by Kenneth Gordon before the Institute of Fuel ; it
The earlier work of Bergius is now well known to those interested: it took him some time to reach the stage of the two-litre converter illustrated here (Fig. 1). Fig. 2, showing a single hydrogenation stall or unit at Billingham, indicates the growth of the process on the engineering side, though its practical development is due also to certain chemical discoveries, notably the favourable influence of adding hydrogen chloride during hydrogenation and its subsequent removal with a stable suspension of alkali in oil from the hot vapours. * Department of Scientific and Industrial Research : Fuel Research.
Technical Paper No. 42: 'The Action of Hydrogen upon Coal. Part 2 : Technical Paper No. 42: The Action of Hydrogen upon Coal. Part 2 Early Experiments with the Bergius Process. By Dr. L. Horton, House, Kingsway, London, W.C.2: H.M. Stationery Office, 1935.) 18. 3d. net. 
At a time when the Bergius experiments at Mannheim-Rheinau were languishing, they were revivified by the British Bergius Syndicate, formed largely by the efforts of Dr. Ormandy, which had for its object the proving of the process with British coals. After a time it was decided by the Government that the Department of Scientific and Industrial Research should proceed with the investigations, and towards the end of 1926, a plant embodying the latest improvements resulting from the work at Rheinau was installed at Greenwich, the small-scale experiments in Rheinau being terminated. The British Bergius Syndicate was behind in such developments, for which the credit is too often given to foreign scientific workers.

The work done on hydrogenation at Greenwich, though it has not yet developed to anything of industrial importance bringing a direct return to the nation; is of outstanding value both as serving to introduce the high-pressure technique into its laboratories and as-securing that independent and continued study of hydrogenation which is so desirable.

The experiments recorded in the Fuel Research Board Technical Paper No, 42 referred to above are now largely of academic interest, but they

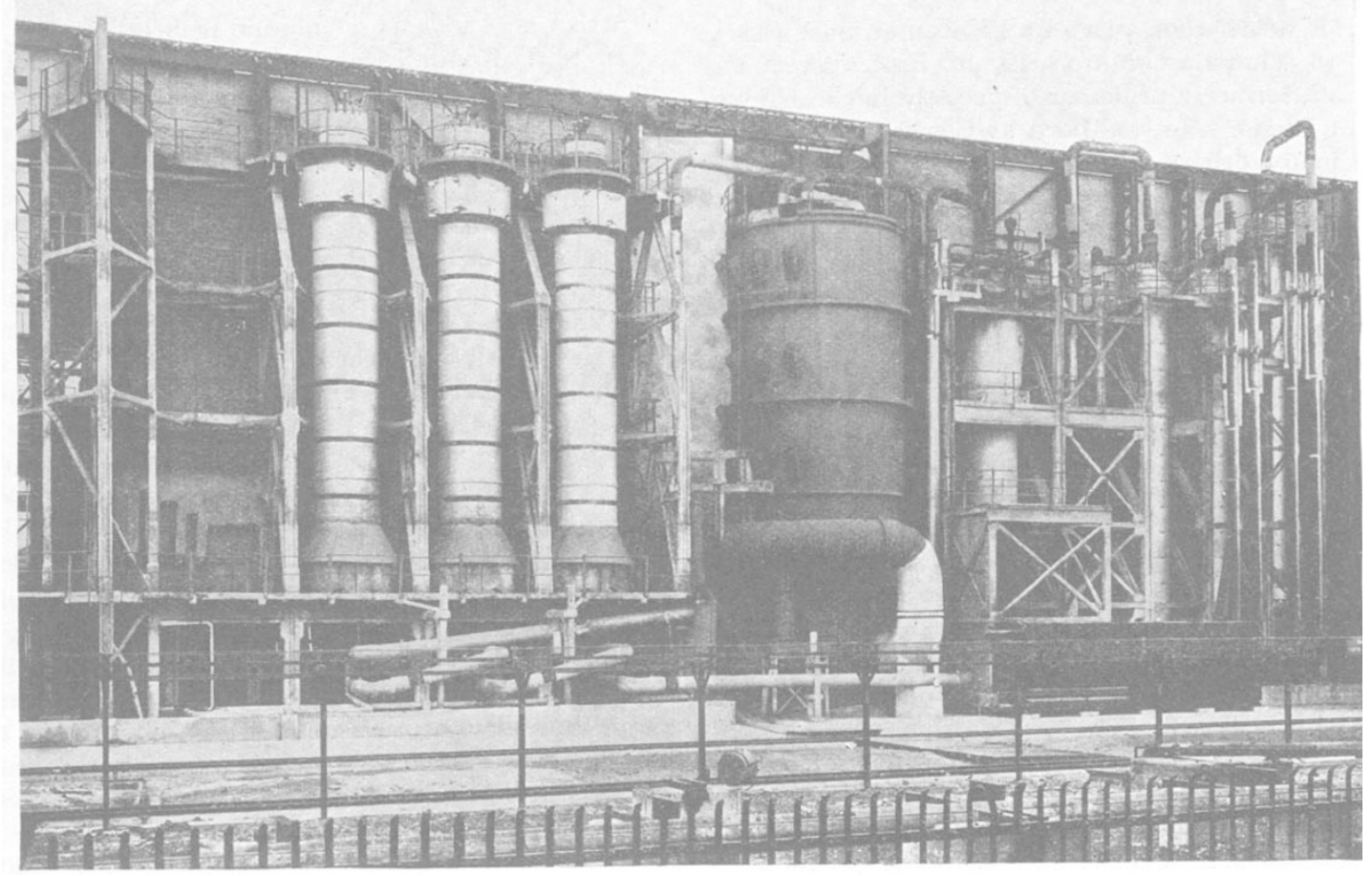

FiG. 2. General arrangement of a hydrogenation stall at Billingham. By courtesy of Imperial Chemical Industries, Ltd.

acquired by I.C.I. in 1927, which started independent research at Billingham on a rapidly growing scale, so that by the end of 1933 the cost had amounted to approximately $£ 1,000,000$ : this is the outstanding example of the complexity and the high cost of working out a new chemical process to the point of industrial practicability. Such a cost makes it difficult for any one other than a large and prosperous company, or an association backed by ample Government support, to investigate new processes. The 'City', though apparently prepared to spend large sums to prove and develop a potential gold mine, will not support as a rule the development of elaborate industrial processes, though it is willing to buy them from abroad when developed. As a consequence, England is perforce content to lag serve to show that catalytic hydrogenation under pressure is widely applicable to British coals. An earlier Technical Paper (No. 29) deals with observations on the conversion of a non-coking into a coking coal when heated with hydrogen under pressure.

Such work is preliminary to the day when it will be realised that coal is in fact a chemical raw material and that there are many different kinds of it. Each will have to be treated in the most appropriate manner to give gaseous, liquid and solid products. The burning of raw coal will be regarded as waste, and coke of excellent quality will be available for metallurgical and domestic purposes according to its nature. The total value of these products should be far in excess of the mining cost of the coal plus the factory costs of 
its subsequent elaboration, and allow of satisfactory employment to miner and factory worker and profit to mine-owner and chemical factory.

The coal question includes many pressing problems, as has been indicated. With defence in mind, the importance of home-produced oil seems paramount, and the Fuel Research Board should be urged to encourage the active study of other methods of making this, for example, from coke via water gas. Unless and until oil can be found deep down in our strata, we must depend on its production from coal and be satisfied that the amount so obtained bears a far larger proportion of the whole quantity used than is at present a fact.

\section{Obituary}

Prof. P. F. Kendall, F.R.S.

$\mathrm{T}$ HE death took place at Frinton-on-Sea, Essex, on Thursday, March 19, of Prof. Percy Fry Kendall, formerly professor of geology in the University of Leeds. He was born at Clerkenwell in 1856. Like many others whose names are famous in the annals of geological science, Kendall was a product of the old Science and Art Department at South Kensington, and in the year 1874 he was awarded the Silver Medal of the Department, this being, the writer believes, the only occasion when such a distinction was gained by a student in geology.

Kendall entered the Science School, South Kensington in 1883 and here he came under the influence of those two great teachers, Judd in geology and Huxley in biology, with the result that he was most attracted to the biological aspects of geology, and his earliest work was upon the fossil fauna of the Pliocene deposits of East Anglia. It is interesting to record that he again took up research on these same deposits in his last years when resident at Frinton, and published a further contribution on the same subject. After leaving South Kensington he was elected Berkeley fellow of Owens College, Manchester, and was later appointed assistant lecturer in geology with Prof. (later Sir) W. Boyd Dawkins, who then occupied the chair of geology at Owens College.

Kendall had become interested in glacial geology by this time, and at the British Association meeting at Manchester in 1887, he had the good fortune to meet the brilliant American glacialist, Prof. Carvill Lewis, and encouraged by him, Kendall from that time devoted himself wholeheartedly to glacial studies. In the 'eighties, the problems connected with the Great Ice Age were receiving much attention, and he ranged himself with those few British geologists who argued that these islands had been covered by land ice, as Greenland is to-day, as opposed to those in the majority, who invoked submergence in an arctic sea with abundance of icebergs as being the best explanation of the deposits of that period. Many a pitched battle was fought upon this question in Section C of the British Association, the honours eventually all resting with the adherents of the land ice theory, of whom Kendall was one of the very foremost. His ready wit and command of language rendered him a doughty champion of any cause he espoused. He was spoken of by one veteran Scottish geologist as a "bonnie fechter".

In 1891, Kendall was appointed part-time lecturer in geology at the Yorkshire College (now University of Leeds) and he at once commenced the investigation of the glaciation of the Cleveland Hills in north-east Yorkshire. To enable him to do this the more successfully, he visited Norway to study the effects of modern glaciers and also to examine in situ those rocks which he was finding as pebbles in the drift-of the Yorkshire coast. Switzerland also gave him many ideas, especially with regard to ice-dammed lakes such as the Marjelen See. The results of these researches were presented to the London Geological Society in a paper entitled "Glacier Lakes in the Cleveland Hills". This was published in 1902 and was an inspiration to many workers, who applied similar methods of investigation to other districts in the British Isles.

While prosecuting his glacial researches Kendall had also paid much attention to the solid geology of Yorkshire. It was part of his duties at Leeds to lecture to students of coal mining, and in order to equip himself more thoroughly for this work he took up the study of the Coal Measures, and in this branch of geology he proved himself as original an investi. gator as he had already done in glacial geology. For the Royal Commission on Coal Supplies in 1901-5 under the chairmanship of Lord Allerton, Prof. Kendall was asked to report upon the Yorkshire, Nottinghamshire and Derbyshire Coalfield, and in the attempt to determine the boundaries of the con. cealed coalfield on the north-east and south, where the Coal Measures are overlain uncomformably by newer rocks, he applied the principle of 'posthumous folding', the argument being that the foldings traceable in the newer covering rocks represent renewed activity along lines of folding already established in the older rocks below before the newer rocks had been laid down. The total area of the unproved coalfield was by this means estimated by Prof. Kendall to be 3,885 square miles, and whether or not this be established by future exploration, it is still true to say that the report forms a most stimulating and illuminating contribution to the tectonics of this great coalfield.

Another phase of Coal Measure geology engaged Kendall's attention for some years, namely, the abnormalities of coal seams and the adjacent beds 